\title{
Teaching and Learning in Higher Education in Albania
}

\author{
Kseanela Sotirofski \\ University "A. Moisi", Faculty of Education \\ nelasotiri@yahoo.com
}

\section{Doi:10.5901/jesr.2014.v4n3p529}

\begin{abstract}
Recent developments are outlined in this paper in the sector of Higher Education of Albania and their implications about the organization of teaching and learning ways. The first part describes and characterizes the contemporary student population as diverse, oriented toward client and goals. Therefore, come presented two teaching and learning models: first is a model of 'deficit' with an approach driven by curriculum with the teacher in centre; the second is characterised with the student in centre and with comprehension of the process of learning. This second model is said to have larger opportunities for the promotion of learning effectiveness since it includes several elements which are key relevant to the current student body and offer improved learning conditions which place emphasis on the interaction and dialogue to promote learning, experimental learning value and leaners needs for learning reflection.
\end{abstract}

\section{Students in Albanian Higher Education}

Students who study in the sector of Higher Education (HE) might be considered in several ways, due to changes in the policies of government and more flexible study programmes like policies that brought to widening access since the initiatives of government to raise students' number at universities. Now there are more students at universities than 20 years ago and pay more than they used to pay for they school fees so there is a twofold net effect of these changes where first of all, students have higher expectations and secondly, students are forced to take part-time jobs because of these financial burdens as well the impossibility to receive grants. As a result, they will have less time to study. Moreover, HE students expect less study and more class study. This means that they expect their studies to be supported in lectures, online reading as crucial to their habits.

Because of the widening access, students are not anymore a homogenous population but mixed in their abilities and educational, social, economic backgrounds from these diverse abilities and backgrounds, the student might get lost and struggle with the subject matter. There is enough evidence to show that mass lecture does nothing to promote effective learning.

\section{A Deficit Model of Teaching and Learning}

This model tended to concentrate on differences among individual learners and characteristics for the good and bad students. Teachers motto was 'blame the student' to explain failure of poor motivation, low interest, low levels of ability etc., rather than seeking explanation to teachers and not criticise learners. This way is quantitative, a way of looking at teaching and learning by only assessment measurement which says that a successful teacher of university is the teacher of students who have high assessment marks rather than the teacher who has motivated, interested or engaged in matter students.

\section{An Alternative Model of Teaching and Learning}

The trend of having student in centre promoted an understanding and development of students learning According to Biggs (2003, p68):

Learning is [....] a way of interacting with the world. As we learn, our conceptions of phenomena change, and we see the world differently. The acquisition of information itself does not bring about such a change, but the way we structure that information and think with it does...Education is about conceptual change, not just the acquisition of information. 
From this quotation comes learning as not a fixed concept, but a constant concept that changes over time and with world interactions. Second, while gaining new knowledge students change their way of thinking. Third, according to quotation above, new meanings are not transmitted simply by means of direct instructions. In fact, there are several stages to pass for new meaning to be constructed relating to previous knowledge, learning motives etc.

Adopting this dynamic fluid of learning view, we can understand better university teacher role to promote students acquisition for effective knowledge.

It is evident that are certain good or bad learning conditions which the teacher is responsible.

1. Understanding occurs through interaction

2. Experiential learning promotes deep understanding

3. Dialogue assists and shapes understandings

4. Learners play an active role in the learning process

5. Learners are encouraged to reflect on their learning

\subsection{Understanding occurs through interaction}

The role of interaction in teaching and learning has been documented from some time now (Swain, 1995, 2005). Since it reveals what is happening, teaching and learning deserves active study. Students when interacting with others can find meanings, ideas, develop critical thinking, make new hypothesis, acquire new understandings. Firstly, 'interaction is the most important element in the curriculum' (van Lier, 1996). The position taken here coincides with that of Ellis (2000), 'learning arises not through interaction, but in interaction'

Second, 'good teaching' has to do more than just good planning. According to van Lier (1996), teaching has two essential ingredients: planning and improvising.

Decisions made at the moment are good if they are appropriate to the moment and not decisions following the plan.

\subsection{Experiential learning promotes deep understanding}

When students are actively engaged in the learning process, it is highly likely that they will experience what Biggs (2003) refers to as 'deep learning'. This is related with the word task, which means tasks should make students engage in meaningful things that end in acquiring new skill or new knowledge, communication skills, teamwork and the use of ICT.

\subsection{Dialogue assists and shapes understandings}

For many educationists, dialogue is central to learning: 'much learning is an activity that occurs in and through dialogues' (Swain, 1995). Only when students discuss and comment their tasks or work gets a deeper understanding. Teacher and peer dialogue make student acquire discipline language and become members of community. According to Musumeci (1996), for example, students of science who master and use its vocabulary and terminology from an early stage consistently attain the highest assessment scores.

Here in this process, the role of teacher is important in stages like clarification, paraphrasing, scaffolding necessary concepts and language used by students.

Scaffolding involves 'feeding in' new language or ideas at a point where they are deemed to be needed. Before scaffolding, some effort is needed for the process and teachers should not interrupt and begin scaffolding early.

\subsection{Learners play an active role in the learning process}

Learners' role is important according to the learning environment. When learners engage actively and work on tasks they should be responsible for their task. This might include decision-making of the group regarding task nature, negotiation for the adopted approach, taking into consideration the ways of outcomes evaluation and presentation of results to the groups. Learners must be taught to work as team members, take their own responsibility for their actions and their decisions. The notion of learner autonomy has been with us for some time (Schmenk, 2005). This concepts stands on the idea that teachers must take into consideration promoting autonomy of the learner and help them achieve this autonomy by encouragement upon reflecting on their works, evaluating their habits of study, writing commentaries on their approach etc. 


\section{Conclusions}

There are many new challenges for the students and lecturers due to the recent changes in the Albanian Higher Education sector and because of that it is obvious that there can be opportunities to enhance teaching and learning sector of higher education. The emphasis placed on teaching with student in centre, promotion of interaction and critical development contribute in student experience improvement and maximizes potential of learning.

\section{References}

Biggs, J. (2003) Teaching for Quality Learning at University. Buckingham, SRHE and Open University.

Ellis, R. (2000) Task-based Research and Language Pedagogy. Language Teaching Research, 49/3: 193-220.

Musumeci, D. (1996) Teacher-learner negotiation in content-based instruction: communication at cross-purposes? Applied Linguistics, $17,286-325$.

Schmenk, B. (2005) Globalizing leaner autonomy. TESOL Quarterly, 39, 107-118.

Swain, M. (1995) Three functions of output in second language learning. In G. Cook and B. Seidelhofer (eds) Principle and Practice in Applied Linguistics: studies in honour of H.G. Widdowson. Oxford, Oxford University Press.

Swain, M. (2005) The output hypothesis: theory and research. In E. Hinkel (ed.) Handbook on Research in Second Language Teaching and Learning. Mahwah, NJ, Lawrence Erlbaum.

van Lier, L. (1996) Interaction in the Language Curriculum: awareness, autonomy and authenticity, New York, Longman 